\title{
Clinical Evaluation of Qat Chewing on the Buccal Mucosa among Secondary Schools Students in Sana'a City, Yemen
}

\author{
Khaled A. AL-Jawfi * \\ Associate Professor of Oral Pathology, Oral Pathology Unit, Department of Biological \& Preventive Sciences, \\ College of Dentistry, University of Science \& Technology, Sana'a, Yemen \\ *Corresponding Author: Khaled A. AL-Jawfi, Associate Professor of Oral Pathology, Oral Pathology \\ Unit, Department of Biological \& Preventive Sciences, College of Dentistry, University of Science \& \\ Technology, Sana'a, Yemen. Email: aljawfi1970@yahoo.com
}

\begin{abstract}
Objective: This study was designed to evaluate qat chewing clinically on the buccal mucosa among secondary schools students in Sana'a city, Yemen.

Methods: This study was conducted on (600) of secondary schools students,(300) male students and (300) female students with an age ranged from $16-20$ years. The sample was collected from five private and five public schools at Sana'a city, Yemen. Students were examined at schools, under natural day light with a disposable mouth mirrors, using gloves and gauze pads.

Results: Normal buccal mucosa (88.8\%\%) was the most prevalent clinical feature, followed by linea alba was (8\%), and the least prevalent clinical feature was whitish area (3.2\%).

Conclusion: Normal buccal mucosa was the commonest clinical feature and it was more common in female students than male students, while the least clinical feature was whitish area and it was more common in male students than female students.
\end{abstract}

Keywords: Clinical Evaluation, Qat Chewing, Secondary School Students, Sana'a City, Yemen.

\section{INTRODUCTION}

Qat is an evergreen plant grown in the regions around the horn of Africa and the Southern Arabian Peninsula such as Yemen, where it up to $90 \%$ of adult males and more than half of adult females are estimated to chew qat for several hours. ${ }^{(1)}$

In Yemen, qat is commonly used for social recreation. Occupational groups such as motor vehicle drivers and truck drivers chew qat during long distance driving to keep them awake; those in cutting of rock stone and building establishment, also use it under a variety of other conditions. A significant number of students chew qat to be alert especially during examination periods. ${ }^{(2)}$

Habitual chewing of qat leaves by Yemeni women over decades caused mucosal white lesions recorded on the chewing side irrespective of additional noxae as tobacco and water-pipe smoking. ${ }^{(3)}$

During qat chewing sessions, large amounts of qat leaves, shoots, and barks are placed in the oral cavity and chewed while being kept in the vestibule in close contact with the buccal mucosa. ${ }^{(4)}$ Qat bolus is chewed gradually and continuously for 2 to 10 hours. On average, $100-500 \mathrm{~g}$ of qat is chewed by chronic users per day. ${ }^{(5)}$ Over 90 percent of the alkaloid content of qat is extracted into saliva during chewing and most of it is absorbed through the oral mucosa. ${ }^{(6)}$ Therefore, the oral mucosa are exposed to high doses of qat constituents during qat chewing rendering them susceptible to its potentially toxic effects. ${ }^{(7)}$

Qat chewing may result in a number of changes in the oral mucosa and the dentition. The mechanical and chemical irritation may result in the development of mucosal white lesions and dark pigmentation. Qat chewing may reduce aspects related to risk of gingival and periodontal inflammation, but it appears to be associated with attachment loss at the site of chewing. ${ }^{(8)}$

\section{MATERIALS AND METHODS}

\subsection{The sample}

This study was conducted on (600) of secondary schools students, (300) male students and (300) 
female students with an age ranged from 16 to 20 years. It was conducted at secondary schools students (five private and five public schools according to a recent geographical map) at Sana'a city in Republic of Yemen through the period from February to May 2017.

\subsection{Examination of Students}

Before the examination started, The examiner gave information for the students about habitual qat chewing and its risk effects. Students were examined at the schools during class hours at their desks in the classroom, in a predetermined timetable, as arranged with the schools principals. Each student was examined to diagnose the buccal mucosa in the natural light with a disposable mouth mirrors, using gloves and gauze pads. A data collecting chart was designed for recording the necessary information's for each student including personal data as name, age, gender and birth date.

\section{RESUltS}

This study was conducted to evaluate qat chewing clinically on the buccal mucosa among secondary schools students in Sana'a city, with age ranged from 16-20 years. The sample size included 600 students randomly selected through cluster sampling, 300 male students $(50 \%)$ and 300 female students (50\%) respectively.

Distribution of qat chewing students in secondary schools according to age \& gender is summarized in table (1), which shows the following results:

In both males \& females, students who chewed qat were less in number at age of 16 year $(n=$ 35 ) and more in number at age of 20 year $(\mathrm{n}=259)$.

Male students who chewed qat were less in number at Hail Saeed school $(\mathrm{n}=56)$, whereas they were more in number at Alkebsi school $(\mathrm{n}=68)$.

Female students who chewed qat were less in number at Shuhda Alsabeen school $(\mathrm{n}=50)$, whereas they were more in number at Alkhansa school $(n=66)$.

In this study, female students who chewed qat were less in number at Shuhda Alsabeen school $(\mathrm{n}=50)$, whereas male students were more in number at Alkhansa school $(\mathrm{n}=68)$.

Table1. Distribution of qat chewing students in secondary schools according to age \& gender

\begin{tabular}{|c|c|c|c|c|c|c|c|c|c|}
\hline \multirow[t]{2}{*}{ No. } & \multirow{2}{*}{$\begin{array}{l}\text { Name of Secondary } \\
\text { School }\end{array}$} & \multirow[t]{2}{*}{ Gender } & \multicolumn{5}{|c|}{ Number of Students By Age } & \multirow[t]{2}{*}{ Total } & \multirow{2}{*}{$\begin{array}{c}\text { Total } \\
\text { By } \\
\text { Gender }\end{array}$} \\
\hline & & & $16 \mathrm{Y}$. & $17 \mathrm{Y}$. & $18 Y$. & $19 Y$. & $20 Y$. & & \\
\hline 1- & Alkebsi & \multirow[t]{5}{*}{ Males } & 4 & 12 & 14 & 17 & 21 & 68 & \multirow[t]{5}{*}{300} \\
\hline 2- & Alkuwait & & 3 & 7 & 9 & 15 & 23 & 57 & \\
\hline 3- & Omar Ibn Abdul Aziz & & 5 & 8 & 10 & 16 & 22 & 61 & \\
\hline 4- & Hail Saeed & & 5 & 7 & 11 & 14 & 19 & 56 & \\
\hline 5- & Alshaab & & 3 & 8 & 9 & 18 & 20 & 58 & \\
\hline 6- & Alramah & \multirow[t]{5}{*}{ Females } & 4 & 9 & 12 & 15 & 24 & 64 & \multirow[t]{5}{*}{300} \\
\hline 7- & Shuhda Alsabeen & & 2 & 7 & 10 & 13 & 18 & 50 & \\
\hline 8- & Shuhda Aljaweeh & & 3 & 10 & 13 & 15 & 21 & 62 & \\
\hline 9- & Balqees & & 3 & 8 & 11 & 17 & 19 & 58 & \\
\hline 10- & Alkhansa & & 3 & 9 & 14 & 18 & 22 & 66 & \\
\hline \multicolumn{3}{|c|}{ Total By Age } & 35 & 85 & 113 & 158 & 209 & \multicolumn{2}{|c|}{600} \\
\hline
\end{tabular}

Distribution of qat chewing students in

of buccal mucosa is summarized in table (2), secondary schools according to clinical features

which shows the following results:

Table2. Distribution of qat chewing students in secondary schools according to clinical features of buccal тисова

\begin{tabular}{|c|c|c|c|c|c|c|}
\hline \multirow{2}{*}{ No. } & \multirow{2}{*}{$\begin{array}{c}\text { Name of Secondary } \\
\text { School } \\
\end{array}$} & \multirow{2}{*}{ Gender } & \multicolumn{3}{|c|}{ Clinical Features of Buccal Mucosa } & \multirow{2}{*}{ Total } \\
\hline & & & Normal & Linea alba & Whitish area & \\
\hline 1- & Alkebsi & \multirow{6}{*}{ Males } & 57 & 7 & 4 & 68 \\
\hline 2- & Alkuwait & & 46 & 8 & 3 & 57 \\
\hline 3- & Omar Ibn Abdul Aziz & & 49 & 9 & 3 & 61 \\
\hline 4- & Hail Saeed & & 48 & 6 & 2 & 56 \\
\hline 5- & Alshaab & & 51 & 5 & 2 & 58 \\
\hline & \& Percentage By Males & & $251(41.8 \%)$ & $35(5.8 \%)$ & $14(2.3 \%)$ & 300 \\
\hline 6- & Alramah & \multirow{3}{*}{ Females } & 59 & 3 & 2 & 64 \\
\hline $7-$ & Shuhda Alsabeen & & 48 & 2 & $\mathbf{0}$ & 50 \\
\hline 8- & Shuhda Aljaweeh & & 57 & 4 & 1 & 62 \\
\hline
\end{tabular}


Clinical Evaluation of Qat Chewing on the Buccal Mucosa among Secondary Schools Students in Sana'a City, Yemen

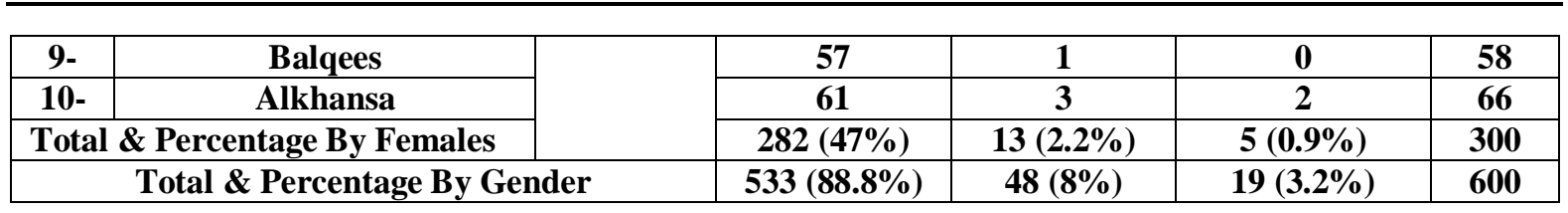

Normal buccal mucosa was seen in 533 students $(88.8 \%)$. The number of normal buccal mucosa in male students was $251(41.8 \%)$ and 282 $(47 \%)$ in female students. It was common in female students than in male students, figures $(1,2)$.

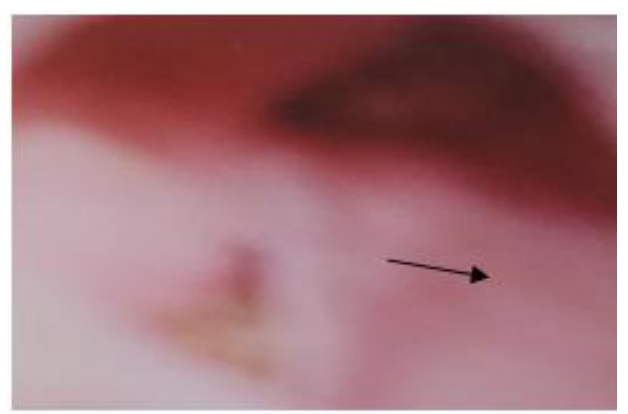

Fig1. Photograph showing normal buccal mucosa in female student

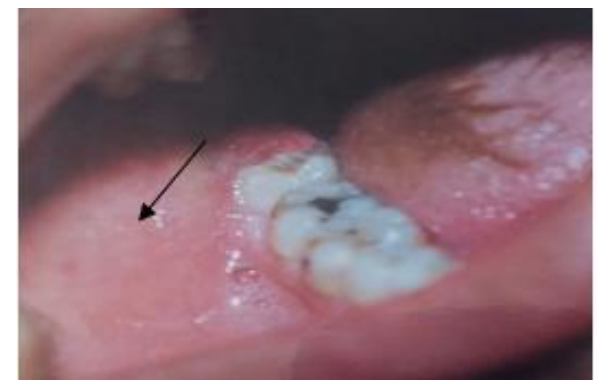

Fig2. Photograph showing normal buccal mucosa in male student

Linea alba was seen in 48 students $(8 \%)$. The number of linea alba in male students was 35 $(5.8 \%)$ and $13(2.2 \%)$ in female students. It was common in male students than in female students, figure (3).

Whitish area was seen in 19 students (3.2 $\%)$. The number of whitish area in male students was $14(2.3 \%)$ and $5(0.9 \%)$ in female students. It was common in male students than in female students, figure (4).

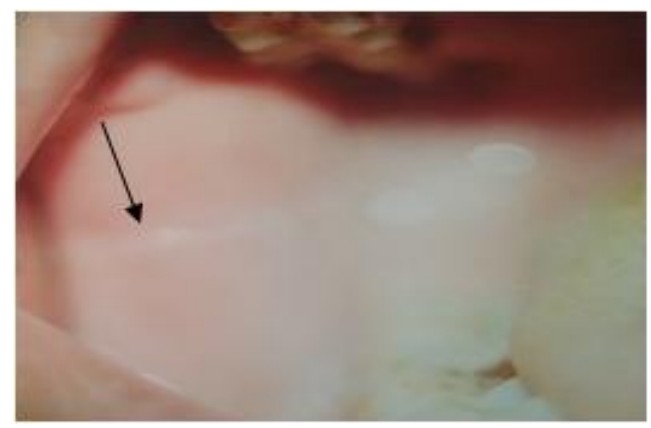

Fig3. Photograph showing linea alba in male student

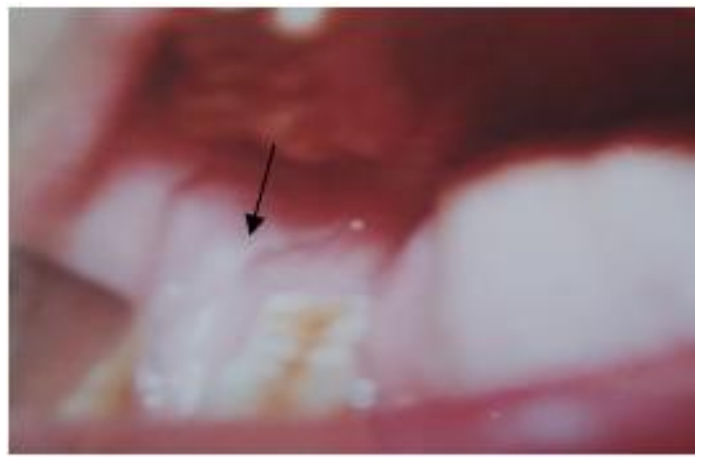

Fig4. Photograph showing whitish area in male student

\section{DISCUSSION}

Although there have been several studies reporting the oral effects of qat chewing on adult $\&$ old age Yemeni population, no reported study has been conducted on Yemeni secondary school students. So this study was done.

In the present study, no premalignant and malignant changes were seen on the buccal mucosa that may be due to the duration and frequency of qat chewing are insufficient to cause any epithelial dysplastic changes. Although It has been speculated that there might be an association between qat chewing and oral malignancies. ${ }^{(9)}$ Buccal epithelial cells experience genotoxic effects in a dose-related way in qat-chewers; this suggests that oral malignancies can be contributed to by qat .The prevalence of this lesion and its severity increased with frequency and duration of qat use. The importance of qat and oral malignancies have been documented after finding that most of the oral squamous cell carcinomas are located in the buccal mucosa which come into direct contact with qat during chewing. ${ }^{(10)}$

Whitish area was the least clinical feature with percentage $(3.2 \%)$ and more common in male students $(2.3 \%)$ than female students $(0.9 \%)$. Whereas it has been reported that that about $50 \%$ of qat chewers develop oral mucosal keratosis. ${ }^{(11)}$ This pathologic change is considered a pre-cancerous lesion that may develop into oral cancer. ${ }^{(\mathbf{1 2})}$ Keratotic white lesions are present in the mouths of about onefifth of qat-chewers. ${ }^{(13)}$

The low prevalence of whitish area in this study does not suggest that qat chewing is a safe habit. 
This is in agreement with Ogada et al.,(2014) who revealed that carcinogenesis is a process that is dependent on several factors including; time, type and amount of exposure to carcinogen and immune status of the individuals. Time is an important factor in carcinogenesis, where it takes about 10-20 years before precursor lesions develop into cancer. This therefore explains the reason for low prevalence in this generally younger population. $^{(14)}$

Linea alba was recorded in this study (8\%) at the buccal mucosa of qat chewing site and more common in male students $(5.8 \%)$ than female students $(2.2 \%)$. It may be due to friction mechanism during qat chewing. This finding is in agreement with Al-Kholani (2010), who reported that the hardness of the qat leaves and friction mechanism with mucosal tissues might act as a predisposing factor in the occurrence of ulcers among chewers which usually observed at the qat chewing sites only. ${ }^{(2)}$

The clinical features of qat chewing on the buccal mucosa in this study ranged from normal to linea alba to whitish area. These findings are in disagreement with another study indicated that the clinicopathological effects of qat chewing on the oral mucosa included different grades of keratotic white lesions, keratinization of non-keratinized oral mucosa and epithelial dysplasia. It may be due to difference in sample age and size. ${ }^{(15)}$ Other genetic study showed that qat consumption, especially when accompanied by tobacco consumption might be a potential cause of oral malignancy. ${ }^{(10)}$ This finding was supported by another study, which demonstrated that qat chewing as a probable contributing etiological factor of squamous cell carcinoma. ${ }^{(16)}$

Clinical evaluation of qat chewing on the buccal mucosa among secondary schools students is an important to aware the students around the risk effects of qat chewing, and to avoid chewing of qat. This is in agreement with another study revealed that the need for health education and promotion programs to increase the awareness of the problem in the population. Positive long term lifestyle changes, including physical exercise should be established early in life since qat habit tends to start in childhood and progress into adulthood. Health education programs disseminated by the mass media to raise the public awareness should focus on the real impact of the qat chewing habit on students and the misconception that qat enhanced productivity and achievement. ${ }^{(2)}$

\section{CONCLUSION}

It may be concluded that Normal buccal mucosa was the commonest clinical feature and it was more common in female students than male students, while the least clinical feature was whitish area and it was more common in male students than female students.

\section{REFERENCES}

[1] El-Menyar, A. ; Mekkodathil, A.; Al-Thani, H.; and Al-Motarreb, A. :Khat use: history and heart failure. Oman Medical Journal. 2015;30(2):77-82.

[2] Al-Kholani, A.: Influence of Khat Chewing on Periodontal Tissues and Oral Hygiene Status among Yemenis. Dent Res J . 2010; 7(1): 1-6.

[3] Schmidt-Westhausen, A. M. ; Al Sanabani, J. and Al-Sharabi, A. K. :Prevalence of oral white lesions due to qat chewing among women in Yemen. Oral Dis. 2014; 20:675-81.

[4] Sawair, F. A.; Al-Mutwakel, A.; Al-Eryani, K.; Al-Surhy A.; Maruyama, S.; Cheng, J.; AlSharabi, A. and Saku, T. : High relative frequency of oral squamous cell carcinoma in Yemen: qat and tobacco chewing as its aetiological background. International Journal of Environmental Health Research. 2007; 17(3):185-95.

[5] Feyissa, A. M. and Kelly J. P.: A review of the neuropharmacological properties of khat. Progress in Neuro-Psychopharmacology and Biological Psychiatry. 2008;32(5):1147-66.

[6] Toennes, S. W.; Harder, S.; Schramm, M.; Niess, C. and Kauert G. F. : Pharmacokinetics of cathinone, cathine and norephedrine after the chewing of khat leaves. British Journal of Clinical Pharmacology. 2003;56(1):125-30.

[7] Lukandu, O. M., 1 ; Koech, L. S. and Kiarie P. N. :Oral Lesions Induced by Chronic Khat Use Consist Essentially of Thickened Hyperkeratinized Epithelium. Int $\mathrm{J}$ Dent. 2015:104812.

[8] Yarom, N. ; Epstein J. ; Levi, H. ; Porat, D. ; Kaufman, E. and Gorsky, M.: Oral manifestations of habitual khat chewing: a case-control study. Oral surgery, oral medicine, oral pathology, oral radiology and endodontics.2010; 109(6):e60-6.

[9] Soufi, H. E.; Kameswaran, M. and Malatani, T. :Khat and oral cancer. The Journal of laryngology and otology. 1991;105(8):643-5.

[10] Kassie, F. ; Darroudi, F.; Kundi, M.; SchulteHermann, R. and Knasmüller, S. :Khat (Catha edulis) consumption causes genotoxic effects in humans. Int. J. Cancer. 2001;92(3):329-32. 
[11] Hill, C. M. and Gibson, A.: The oral and dental effects of khat chewing. Oral surgery oral medicine oral pathology oral radiology and endodontic. 1987; 63:433-6.

[12] Goldenberg, D. ; Lee, J. and Koch, W. M. et al. :Habitual risk factors for head and neck cancer. Otolaryngol Head Neck Surgery. 2004; 131(6):986-93.

[13] Ali, A. A.: Histopathologic changes in oral mucosa of Yemenis addicted to water-pipe and cigarette smoking in addition to takhzeen alqat. Oral surgery oral medicine oral pathology oral radiology and endodontics. 2007;(103):559.
[14] Ogada, N. A. ; Muchiri, L. W. and Ndung'u, J. R.: Oral Mucosal Cytological Changes among Miraa Chewers in Meru Kenya. Journal of Dental and Medical Sciences.2014; 13(10): 6889.

[15] Ali, A. A.; Al Sharabi, A. K.; Aguirre, J. M. and Nahas, R.: A study of 342 oral keratotic white lesions induced by qat chewing among 2500 Yemeni. J Oral Pathol Med. 2004; 33 (6):368-72.

[16] Nasr, A. H. and Khatri, M. L.: Head and neck squamous cell carcinoma in Hajjah, Yemen. Saudi Med J. 2000;21(6):565-8

Citation: Khaled A. AL-Jawfi. Clinical Evaluation of Qat Chewing on the Buccal Mucosa among Secondary Schools Students in Sana'a City, Yemen. ARC Journal of Dental science. 2017; 2(4): 15-19. doi:dx.doi.org/ 10.20431/2456-0030. 0204005.

Copyright: (c) 2017 Authors. This is an open-access article distributed under the terms of the Creative Commons Attribution License, which permits unrestricted use, distribution, and reproduction in any medium, provided the original author and source are credited. 